\title{
EHMTI-0009. A particular case of cluster headache
}

\author{
D Tertan ${ }^{1 *}$, OB Tertan ${ }^{2}$ \\ From 4th European Headache and Migraine Trust International Congress: EHMTIC 2014 \\ Copenhagen, Denmark. 18-21 September 2014
}

\section{Introduction}

Cluster headache represents a severe, strictly unillateral retroorbital short lasting headache, accompanied by permanent parasimpathetic autonomic features; attacks occur regularly for one week to one year, separated by pain- free periods that last at least one month.

\section{Aims}

We present a case of cluster headache as the presenting symptom leading, in the end, to the diagnosis of Multiple Sclerosis(MS) with a demyelinating lesion in the left trigeminal nucleus and tract.

\section{Methods}

We reviewed the case retrospectively, including the clinical, laboratory and radiological data.

\section{Results}

Our patient, female, aged 31 years, was admitted to our hospital with attacks of headache of short duration 10-20 minutes, that occur 4-5 times a day, usually during sleeping, accompanied by rhinorrhea, eyelid edem, ptosis, miosis and conjunctival injection. The pain is so excruciating that the patient describes it as "suicide headache", followed by an incomplete abolition of the pain after 50-100 mg Sumatriptane per day, 600 mg Magnesium daily and Capsaicin cream. Cerebrospinal fluid revealed mildly elevated protein. Magnetic resonance imaging showed a non-hancing, non restricting lesion within the pontine portion of the left trigeminal nucleus and tract. There were also numerous periventricular and callosal white T2 hyperintensities consistent with demyelination. The diagnosis of MS was confirmed by additional lesions in the cervical spinal cord, presence of oligoclonal bands, intrathecal Ig $\mathrm{G}$ synthesis.

${ }^{1}$ Neurology, Clinical Hospital Pelican, Oradea, Romania

Full list of author information is available at the end of the article

\section{Conclusion}

The case suggests that in patients with any primary headache, especially young population, neuroimaging is often useful in order to exclude structural lesions.

No conflict of interest.

\section{Authors' details}

${ }^{1}$ Neurology, Clinical Hospital Pelican, Oradea, Romania. ${ }^{2}$ University of

Medicine and Pharmacy, Cluj Napoca, Romania.

Published: 18 September 2014

doi:10.1186/1129-2377-15-S1-C60

Cite this article as: Tertan and Tertan: EHMTI-0009. A particular case of

cluster headache. The Journal of Headache and Pain 2014 15(Suppl 1):C60.

\section{SpringerOpen ${ }^{\odot}$}

(C) 2014 Tertan and Tertan; licensee Springer. This is an Open Access article distributed under the terms of the Creative Commons Attribution License (http://creativecommons.org/licenses/by/2.0), which permits unrestricted use, distribution, and reproduction in any medium, provided the original work is properly cited.
Submit your manuscript to a SpringerOpen ${ }^{\circ}$ journal and benefit from:

- Convenient online submission

- Rigorous peer review

- Immediate publication on acceptance

- Open access: articles freely available online

- High visibility within the field

- Retaining the copyright to your article

Submit your next manuscript at $>$ springeropen.com 